\title{
Substitution between Foreign Capital in China, India, the Rest of the World, and Latin America: Much Ado about Nothing?
}

\author{
Javier Cravino \\ University of California, Los Angeles \\ Daniel Lederman \\ The World Bank \\ Marcelo Olarreaga \\ University of Geneva \\ CEPR
}

\begin{abstract}
This paper explores the impact of the emergence of China and India on Foreign Capital Stocks (FCS) in other economies. Using bilateral FCS data from 19902003 and drawing from the Knowledge-Capital Model of multinational enterprises to control for fundamental determinants of FCS across countries, the evidence suggests that the impact of foreign capital in China and India on other countries' FCS has been positive. This finding is robust across different specifications and estimation techniques. There is surprisingly weak evidence of substitution in manufacturing FCS away from Central America/Mexico in favor of China, and from Southern Cone countries to India, but these findings are not robust to the use of alternative estimation techniques. In sum, fears of a global

\footnotetext{
*Corresponding address: Javier Cravino: University of California, 8283 Bunche Hall, Los Angeles, CA 90095, USA, tel: (1. 202)372.6725), e-mail: jcravino@ucla.edu, Daniel Lederman: Development Research Group, The World Bank, 1818 H Street, NW, Washington DC 20433, USA, Tel: (1.202)473.9015, Fax: (1.202)522.1159, e-mail: dlederman@worldbank.org, Marcelo Olarreaga: University of Geneva, 40 Bd. Pont-d'Arve, 1211 Geneva, Switzerland, Tel: (41.22)379.8286, Fax: (41.22)379.8293, e-mail: olarreaga@ecopo.unige.ch
} 
competition for FDI seem misplaced, and policymakers concerned about attracting foreign investors should focus their efforts on the fundamentals determinants of FDI.

- JEL Classification : F21, F22, O57

- Key Words: foreign direct investment, China, India, Latin America

\section{Introduction}

There is increasing concern in developing countries about competition from China and India in the attraction of Foreign Direct Investment (FDI). The outstanding economic growth, together with the large populations and low wages in these emerging economies make them particularly attractive to foreign investors. In fact, China and India have been ranked the two most attractive global business locations by transnational companies in UNCTAD's survey of FDI prospects. ${ }^{1}$

The emergence of China and India as potential competitors for FDI, together with a slowdown in FDI inflows to other developing countries at the beginning of the $21^{\text {st }}$ Century raised the alarm. For many, the relocation of production facilities from, for example, Latin America and the Caribbean (LAC) to China and India has already begun. The World Investment Directory claims that “... [the] relocation of the maquila industry was largely, but not exclusively, due to fiercer competition from Asia”, when referring to the slowdown in Mexico's FDI inflows. ${ }^{2}$

A first look at the data reveals that Foreign Capital Stocks (FCS) have become increasingly important in developing countries, including LAC, during the past 15 years. By 2004, aggregate stocks in LAC reached $\$ 600$ billion dollars, about six times more than in $1990 .{ }^{3}$ More than 80 percent of these stocks are concentrated in five countries, namely Argentina, Brazil, Chile, Mexico, and Venezuela. Over the same period, FCS in China grew at an even faster speed, from \$20 billion in 1990 to $\$ 245$ billion in 2004 , the largest FCS in the developing world. FCS in India increased from $\$ 1.6$ to almost $\$ 40$ billion during the same period.

The effect of FCS in China and India on other economies is theoretically ambiguous. For China and India to have a negative effect on others, global FDI

${ }^{1}$ UNCTAD (2005) FDI prospects survey.

${ }^{2}$ UNCTAD (2004).

${ }^{3}$ UNCTAD, Foreign Direct Investment Database (www.unctad.org). We do not include Bermuda, Cayman Islands and Virgin Islands in the Latin American figures as part of LAC. 
supply would have to be inelastic, as well as globally integrated so that competition for FDI becomes a zero-sum game. However, as noted by Eichengreen and Tong (2005), if production processes are vertically integrated across countries, increasing production in China or India would require increasing production in other locations. Therefore, empirical work is needed to ascertain whether the growth of China and India have been complements or substitutes for foreign capital in alternative locations.

There is a recent literature that estimates econometrically the impact of China's emergence as a large host of foreign capital on the developing world. For example, Chantasasawat et al. (2004) use data on aggregate FDI inflows for a group of Asian and Latin American countries. After controlling for other FDI determinants, they find that China's FDI is positively correlated with inflows to East and Southeast Asia and insignificantly correlated with FDI to Latin America. In contrast, Marcereau (2005) finds a substitution effect between China and other Asian countries, although this effect is driven by two countries, Singapore and Myanmar. Garcia-Herrero and Santabarbara (2005) use bilateral data on FDI among source-host country pairs during 1984-2001 and do not find a substitution effect between Chinese and Latin American FDI. However, they do find a negative relationship between China and Latin American inflows when they focus on 19952001, especially for Mexico and Colombia. Eichengreen and Tong (2005) use a "gravity model" of bilateral FDI that controls for countries' GDPs, GDP per capita, and other variables used in the standard trade gravity model, such as distance and common language between host and source countries. They then augment this model with China's FDI inflows, and find that China has a positive effect on inflows to other developing countries but no effect on Latin America.

Our contribution is threefold. First, like others we estimate the impact of the growth of the OECD's stock of foreign capital in China and India on OECD's investment in other countries, but contrary to previous studies which rely on the gravity model of trade, we base our methodology on a model of outward foreign investment, namely the "Knowledge-Capital Model" (KCM). The KCM is grounded on the theory of the multinational enterprise and has been estimated in recent papers by Carr, Maskus and Markusen (2001), Blonigen, Head and Davis (2003), and Blonigen and Davies (2002).

Second, the existing literature assumes that the effect of China is homogeneous across sectors. In fact, the available data on U.S. foreign capital abroad indicates that the evolution of manufacturing-sector FCS across countries has been different 
from the trends of aggregate FCS (Cravino, Lederman, and Olarreaga 2006). The manufacturing sector seems particularly sensitive to relocation of multinationals into China and India as they search for lower labor costs. Thus, we take an additional step and estimate the effects of China and India on manufacturing-sector FCS in other countries, based on data on outward FCS from the U.S.

Third, the existing literature uses exclusively OLS or other linear estimators. In the context of the gravity model of international trade, it is now known that such linear estimators can yield inconsistent coefficients due to the correlation between the expected value of bilateral trade flows among country pairs and the variance of their regression errors (Santos Silva and Tenreyro 2006). The same is likely to occur when we estimate log linear models of bilateral foreign investment. We therefore provide estimates that correct for this bias.

Our results suggest that there is no substitution effect between FCS in China and India and those in LAC or other hosts of FCS. When using sector-level FCS data from the U.S., we continue to find that there is no robust substitution effect from China or India on manufacturing-sector FCS in other countries, including LAC and Central America and Mexico. In some cases we cannot reject the hypothesis of no substitution effect of Chinese FCS on Central America and Mexico or of Indian FCS on FCS in the Southern Cone countries of LAC. When we do find substitution effects, the results are not robust across econometric techniques.

The rest of the paper is organized as follows. Section II describes the empirical methodology and section III describes the data and variable construction. Section IV presents and discusses the econometric results. The last section concludes.

\section{Modeling the Determinants of FCS across Countries}

Our approach is similar to the one proposed by Eichengreen and Tong (2005), which is to utilize bilateral FCS in China and India in estimations of the determinants of FCS around the world. However, we use the KCM instead of the gravity model of trade as a benchmark for our regressions, since it is grounded in formal FDI theory (Carr, Markusen, and Maskus 2001). This model allows for both horizontal and vertical motivations for FDI and was estimated in a number of recent papers, including Carr, Markusen, and Maskus (2001); Blonigen, Davies, and Head (2003); and Blonigen and Davies (2004).

As noted by Blonigen and Head, one problem with FDI data is that it is highly skewed. Table A.1 in the appendix shows that the standard deviation in our 
dependent variable is about five times its mean. We therefore follow their specification throughout the paper. Our benchmark regression is then:

$$
\begin{aligned}
& \operatorname{In} F C S_{i j t}=\alpha_{0}+\alpha_{1} \operatorname{In} S U M G D P_{i j t}+\alpha_{2} \operatorname{In} G D P D I F S Q_{i j t}+\alpha_{3}\left|S K D I F F_{i j t}\right|+\alpha_{4} S K D I F F_{-} N E G_{i j t} \\
& +\alpha_{5} \operatorname{In} F_{-} C O S T_{j t}+\alpha_{6} \operatorname{In} T_{-} C O S T_{j t}+\alpha_{7} \operatorname{In} T_{-} C O S T_{j t}+\alpha_{8} \operatorname{In} D I S_{i j t} \\
& +\alpha_{9} \operatorname{In} F C S_{i \text { Chinat }}+\alpha_{10} \operatorname{In} F C S_{-} L A C_{\text {iChinat }}+\alpha_{11} \operatorname{In} F C S_{\text {iIndiat }}+\alpha_{12} \operatorname{In} F C S_{-} L A C_{\text {iIndiat }}+\varepsilon_{i i j t}
\end{aligned}
$$

The first two terms in equation (1) capture the horizontal motivation for FDI. The first independent variable, SUMGDP, refers to the sum of source-country and host-country GDPs and is a measure of total market size. According to the KCM, the coefficient on this variable should be positive, since larger markets should attract multinational enterprises $\left(\alpha_{1}>0\right)$. This variable is thus expected to capture the horizontal motivation for FDI. GDPDIFSQ is the square of the difference of the two countries' GDP. The KCM predicts that, controlling for SUMGDP, differences in country size discourage horizontal FDI. The intuition is that when one of the countries is small, multinational firms would open production facilities mostly in the larger economy, and thus a negative sign on the coefficient of GDPDIFSQ captures this effect $\left(\alpha_{2}>0\right)$.

The next two terms in equation (1) capture the vertical motivations for foreign investment. SKDIFF refers to the difference in skill endowments between the source and the host country. Theory predicts a positive coefficient on this variable $\left(\alpha_{3}>0\right)$, since differences in skill should proxy for differences in wages, which encourage multinational corporations to vertically integrate their production with economies where labor is less costly. Empirical evidence on the impact of relative skill abundance is mixed, however. Blonigen, Davies and Head (BDH) and Maskus and Markusen (1999) found negative coefficients on this variable, indicating that FDI may seek high-skill labor. As noted in BDH, there is also a methodological issue about the interpretation of this variable. When the skill difference is positive (the source country is more skill abundant than the host country), an increase in this variable indicates that the difference in the skills in these countries is rising. In contrast, if the skill difference is negative, an increase in this variable indicates that the countries are becoming more alike. To deal with this issue, we follow BDH and take the absolute value of the skill difference. We then interact this variable with a dummy indicating when the skill difference is negative ( $S K D I F F_{-} N E G$ ), to allow for a smaller coefficient when the host country is relatively more abundant in skilled labor $\left(\alpha_{4}<0\right)$.

The next four terms in the equation capture investment and trade costs. $F_{-} C O S T$ 
is the cost of investing in the host country, which is expected to have a negative effect on FCS $\left(\alpha_{5}<0\right)$. T_Costs capture the trade costs in the source and host countries. In the source country, trade costs should discourage vertical integration FDI by making production abroad less attractive as the costs of exports sent back to the source country reduce firm profits $\left(\alpha_{6}<0\right)$. In contrast, trade costs in the host country favor horizontal FDI to serve the host market, as it creates incentives for tariff-jumping FDI $\left(\alpha_{7}<0\right)$. DIST is the distance between source and host countries. Since distance affects trade and investment costs, its theoretical effect on foreign investment is ambiguous. Previous empirical studies found a negative coefficient on this variable (Carr et al 2001, Blonigen et al 2003), i.e., $\alpha_{8}<0$.

The last terms of the equation are the variables of interest, which capture the impact of China and India on other economies' FCS. FCS $S_{\text {iChinat }}$ is the stock of foreign capital in China coming from source country $i$ at time $t$. Thus a positive coefficient on this variable, $\alpha_{9}>0$, signals that as FDI from OECD countries to China grows so does FDI from OECD countries to the rest of the world. A negative coefficient would signal substitution between China and the rest of the world as hosts for OECD capital. The interaction with a dummy for LAC captures differences between the world average and Latin America. The same logic applies to the last two variables, $F C S_{\text {iIndiat }}$ and $F C_{-} L A C_{\text {iIndiat }}$, but India is the reference country.

FCS data contain negative and zero values, which might be a problem for the log-linear estimations. We address this issue in two ways. First, we follow Blonigen and Davies (2004) and truncate these observations to 0.1. Second, we use a Poisson pseudo maximum likelihood estimator. This approach, proposed by Santos Silva and Tenreyro (2006), has the advantage of not requiring any transformation of the zeros in our dependent variable, which comprise $25 \%$ of our dataset. The Poisson pseudo estimator also allows us to correct for the bias introduced by the correlation between the expected value of bilateral trade flows among country pairs and the variance of the error term. This systematic heteroskedasticity produces log-linear estimates that are driven by the disproportionate influence of observations with high expected bilateral capital stocks. Indeed, Monte Carlo simulations suggest that the application of log-linear estimators to this type of data-generation process tends to produce substantial biases in the coefficients compared to the Poisson estimator, which controls for a constant correlation between the conditional mean of each observation and its regression-error variance. Furthermore, if the data-generation process is 
characterized by over-dispersion (a rising ratio of variance over conditional mean) then the Negative Binomial estimator could be preferable. The data on bilateral FCS seems to be characterized by the same type of systematic heteroskedasticity that afflicts bilateral trade data, and consequently we subject all of our empirical models to the three estimators, namely OLS, Poisson, and Negative Binomials. Santos Silva and Tenreyro (2006) argue that the Negative Binomial estimator might not be desirable if the smaller observations are more prone to measurement errors than the larger observations. ${ }^{4}$ To some extent, the use of outward FCS reported mainly by OECD countries might help deal with this concern, but to err on the side of caution, we report results from all three estimators.

One econometric issue that needs to be addressed concerns the potential endogeneity of foreign capital stocks in China and India. One source of bias might be omitted variables that are correlated with foreign capital stocks in China, India, and the rest of the world. To deal with this concern, country-pair fixed effects control for any time-invariant host and source country specific effect. In this case any time invariant variable, such as geographic distance, drops out from the estimation as it is perfectly collinear with the country-pair fixed effects. Year dummies control for any global shock that may be driving the correlation between stocks of foreign capital in China, India, and the rest of the world, such as a global increase in the supply of foreign capital by the OECD due to, for example, low global interest rates. ${ }^{5}$ We also control for natural resource endowments, which vary across host countries and over time. Omitted variables might be only part of the problem, as reverse causality might bias the estimates of the effects of China and India. We follow most of the literature and assume that most countries, especially Latin American countries, are small so that the decision to invest in China and India by OECD investors is not affected by their decision to invest in each individual LAC country.

\section{Data}

Data on bilateral FCS come from OECD and UNCTAD for the period 1990-

\footnotetext{
${ }^{4}$ Santos Silva and Tenreyro (2005) warn against estimating models were V[y/x] is a function of higher powers of $\mathrm{E}[\mathrm{y} / \mathrm{x}]$ when dealing with trade data. These models might give excessive weight to observations with low trade values, which may be ridden with measurement errors. This observation is less valid for our outward FCS data, since it is collected by OECD countries.

${ }^{5}$ It is noteworthy that the growth of China and perhaps India, with their rising savings, might have contributed to low global interest rates.
} 
2004. The OECD reports bilateral outward FCS of 29 OECD countries in 235 host economies in millions of U.S. dollars from 1982 to 2003. Data from UNCTAD cover 29 source countries in 190 host countries. ${ }^{6}$ The combination of these datasets leaves us with a total of 20,949 observations, of which one fifth come from UNCTAD. ${ }^{7}$ FCS data were deflated using the U.S. producer price index from the IMF's International Financial Statistics (IFS) dataset.

Unfortunately, bilateral outward FCS disaggregated by sector is not available for most OECD countries. The U.S. Bureau of Economic Analysis (BEA) does provide data across sectors. ${ }^{8}$ These stocks are reported on a historical cost basis in millions of U.S. dollars for ten sectors. ${ }^{9}$

GDP in current U.S. dollars was taken from the World Development Indicators(WDI) and deflated by the U.S. producer price index from the International Monetary Fund's International Financial Statistics database. Our measure of skill-labor abundance is the ratio between skilled and unskilled workers which were taken from the often-used education data provided by Barro and Lee (2000).

We include two variables to account for investment costs. As a measure of the host-country political instability we follow Eichengreen and Tong year and use the Political Risk Rating from the International Country Risk Guide data. This index ranges from 0 to 100 , where higher scores indicate more political stability. To clarify the interpretation of this variable's coefficient we redefine this measure as 100 minus the index. We thus expect a negative coefficient on this variable. As a measure of economic volatility we include the volatility of the real exchange rate. We calculate this as the standard deviation of the monthly growth rate of the real exchange rate. ${ }^{10}$

suggesting that China may be diverting manufacturing FCS away from this group of countries. However, this finding is not robust to the use of the Poisson and

\footnotetext{
${ }^{6}$ For those countries for which the UNCTAD data is reported in national currency, we transformed the figures into U.S. dollars using the end of period exchange rate, which was taken from the OECD. We then use the OECD dataset unless the observations are missing. Data for Australia for the period 19902000 was also taken from the UNCTAD, since OECD reports data for the fiscal year.

${ }^{7}$ Missing observations in our right-hand-side variables leave us with a total of 13,765 observations.

${ }^{8}$ www.bea.org

${ }^{9}$ BEA sector classification is SIC until 1998 and NAICS since 1999. However, total stocks in the manufacturing sector are comparable across classifications.

${ }^{10}$ We calculate the RER as the product of the U.S producer price index and the market exchange rate, divided by the consumer price index. These data were taken from the International Monetary Fund's International Financial Statistics database.
} 
For trade costs, we follow the KCM literature and use 100 minus the degree of openness, where openness is the ratio of merchandise imports over GDP. Merchandise imports were taken from the World Trade Organization's database. Finally, the indexes on natural resources are the ratio of a country's sector net exports divided by the labor force. These data were also taken from the World Bank's World Development Indicators' database. Tables A1 and A2 in the appendix contain the summary statistics for the resulting dataset and the list of countries in our sample.

\section{Results}

Table 1 reports the results from a model conditioned only on time effects and country-pair fixed effects. ${ }^{11}$ We present results based on both the OECD/UNCTAD aggregate and U.S. sector FCS data. The point estimates of China's and India's effect on LAC are reported at the bottom of the table. The first panel reports the effect of China and India on aggregate FCS. Column 1 shows the results of the OLS estimation. The impact of China is positive and significant for the rest of the world, and LAC does not appear to be statistically different. The coefficient on the Indian FCS variable also appears with a positive sign and is statistically different from zero. The effect on LAC is not statistically different either, but the corresponding point estimate is positive.

The second column shows the Poisson regression results. We use the Poisson conditional-mean estimator to control for country-pair fixed effects proposed by Hausman et al. (1984). The results are qualitatively similar to those of the OLS estimation, although the magnitudes of the impact of China and India are considerably smaller. We continue to find that China and India have a positive effect on the rest of the world, and the effect on LAC is not different. The overall effects of China and India on LAC are 0.22 and 0.19 respectively, which are about half of the corresponding OLS estimate. The third column shows the estimates for the Negative Binomial conditional-mean estimator also proposed by Hausman et al. (1984). Again, we find that China and India have had a positive effect on FCS in the world and LAC.

The second panel of Table 1 shows the results using the U.S. sector data. As

\footnotetext{
${ }^{11}$ For the sake of brevity, we do not report unconditional partial correlations without time or country-pair fixed effects.
} 
Table 1. Unconditional Coefficients

\begin{tabular}{|c|c|c|c|c|c|c|}
\hline & \multicolumn{3}{|c|}{$\begin{array}{c}\text { Aggregate Regressions } \\
\text { OECD and UNCTAD Data }\end{array}$} & \multicolumn{3}{|c|}{$\begin{array}{c}\text { Sector Regressions } \\
\text { U.S. Data } \\
\end{array}$} \\
\hline & Logs & Poisson & NEG.BIN. & Logs & Poisson & NEG.BIN. \\
\hline China's Effect on Rest of the World (ROW) Foreign & 0.40 & 0.31 & 0.16 & 0.01 & 0.07 & 0.01 \\
\hline Capital Stock (FCS): $\left(F C S_{\text {iChinat }}\right)$ & {$[10.98]^{* *}$} & {$[4.74]^{* *}$} & {$[7.55] * *$} & [1.08] & {$[2.71]^{* *}$} & [0.77] \\
\hline China's Additional Effect on LAC FCS: (FCS_LAC $C_{\text {iChinat }}$ ) & $\begin{array}{c}0.00 \\
{[0.04]}\end{array}$ & $\begin{array}{l}-0.09 \\
{[1.50]}\end{array}$ & $\begin{array}{l}-0.02 \\
{[0.58]}\end{array}$ & $\begin{array}{c}0.03 \\
{[1.70]}\end{array}$ & $\begin{array}{c}0.08 \\
{[1.16]}\end{array}$ & $\begin{array}{c}0.05 \\
{[1.85]}\end{array}$ \\
\hline India's Effect on Rest of the World FCS:( $\left.F C S_{\text {indiat }}\right)$ & $\begin{array}{c}0.38 \\
{[10.19]^{* * *}}\end{array}$ & $\begin{array}{c}0.08 \\
{[2.87]^{* *}}\end{array}$ & $\begin{array}{c}0.07 \\
{[3.61]^{* *}}\end{array}$ & $\begin{array}{c}0.04 \\
{[2.64]^{* *}}\end{array}$ & $\begin{array}{c}0.06 \\
{[1.87]}\end{array}$ & $\begin{array}{c}0.05 \\
{[2.80]^{* *}}\end{array}$ \\
\hline India's Additional Effect on LAC FCS:(FCS_LAC $\left.C_{\text {inddiat }}\right)$ & $\begin{array}{c}0.02 \\
{[0.23]}\end{array}$ & $\begin{array}{c}0.11 \\
{[1.43]}\end{array}$ & $\begin{array}{c}0.00 \\
{[0.07]}\end{array}$ & $\begin{array}{c}-0.04 \\
{[1.56]}\end{array}$ & $\begin{array}{c}-0.08 \\
{[1.65]}\end{array}$ & $\begin{array}{l}-0.03 \\
{[1.10]}\end{array}$ \\
\hline China's Effect on ROW FCS in Manufacturing & & & & $\begin{array}{c}-0.07 \\
{[0.76]}\end{array}$ & $\begin{array}{c}0.04 \\
{[0.69]}\end{array}$ & $\begin{array}{c}-0.04 \\
{[0.58]}\end{array}$ \\
\hline China's Effect on LAC FCS in Manufacturing & & & & $\begin{array}{c}-0.03 \\
{[0.29]}\end{array}$ & $\begin{array}{c}0.10 \\
{[0.77]}\end{array}$ & $\begin{array}{c}-0.05 \\
{[0.60]}\end{array}$ \\
\hline India's Effect on ROW FCS in Manufacturing & & & & $\begin{array}{c}0.06 \\
{[0.35]}\end{array}$ & $\begin{array}{c}-0.41 \\
{[2.57]^{*}}\end{array}$ & $\begin{array}{c}0.21 \\
{[2.07]^{*}}\end{array}$ \\
\hline India's Effect on LAC FCS in Manufacturing & & & & $\begin{array}{c}0.19 \\
{[0.85]}\end{array}$ & $\begin{array}{l}-0.30 \\
{[0.93]}\end{array}$ & $\begin{array}{c}0.03 \\
{[0.22]}\end{array}$ \\
\hline Observations & 11363 & 10651 & 10651 & 6690 & 4971 & 4971 \\
\hline Number of Group(country pairs) & 1486 & 1128 & 1128 & 873 & 603 & 603 \\
\hline \multicolumn{7}{|c|}{$\begin{array}{l}\text { Robust } \mathrm{t} \text { statistics in brackets. Time and country-pair fixed effects are included, but not reported. The panel below reports the corresponding point estimates } \\
\text { th effect of foreign capital stocks in China and India on LAC economies' FCS. } \\
* \text { significant at } 5 \% ; * * \text { significant at } 1 \%\end{array}$} \\
\hline China's Effect on LAC & 0.41 & 0.22 & 0.14 & 0.05 & 0.15 & 0.06 \\
\hline India's Effect on LAC & 0.40 & 0.19 & 0.07 & 0.00 & -0.01 & 0.02 \\
\hline China's Effect on LAC Manufacturing & N.A. & N.A. & N.A. & -0.06 & 0.29 & -0.03 \\
\hline India's Effect on LAC Manufacturing & N.A. & N.A. & N.A. & 0.25 & -0.72 & 0.25 \\
\hline p-value test: China's Effect on LAC $=0$ & 0 & 0 & 0 & 0.01 & 0.02 & 0.01 \\
\hline p-value test: India's Effect on $\mathrm{LAC}=0$ & 0 & 0.01 & 0.04 & 0.89 & 0.67 & 0.44 \\
\hline p-value test: China Effect on LAC Manufacturing $=0$ & N.A. & N.A. & N.A. & 0.51 & 0.00 & 0.72 \\
\hline p-value test: India Effect on LAC Manufacturing $=0$ & N.A. & N.A. & N.A. & 0.20 & 0.03 & 0.01 \\
\hline
\end{tabular}

$\mathrm{LAC}=$ Latin America and the Caribbean 
Table 2. Estimations of the Knowledge Capital Model with China and India Effects

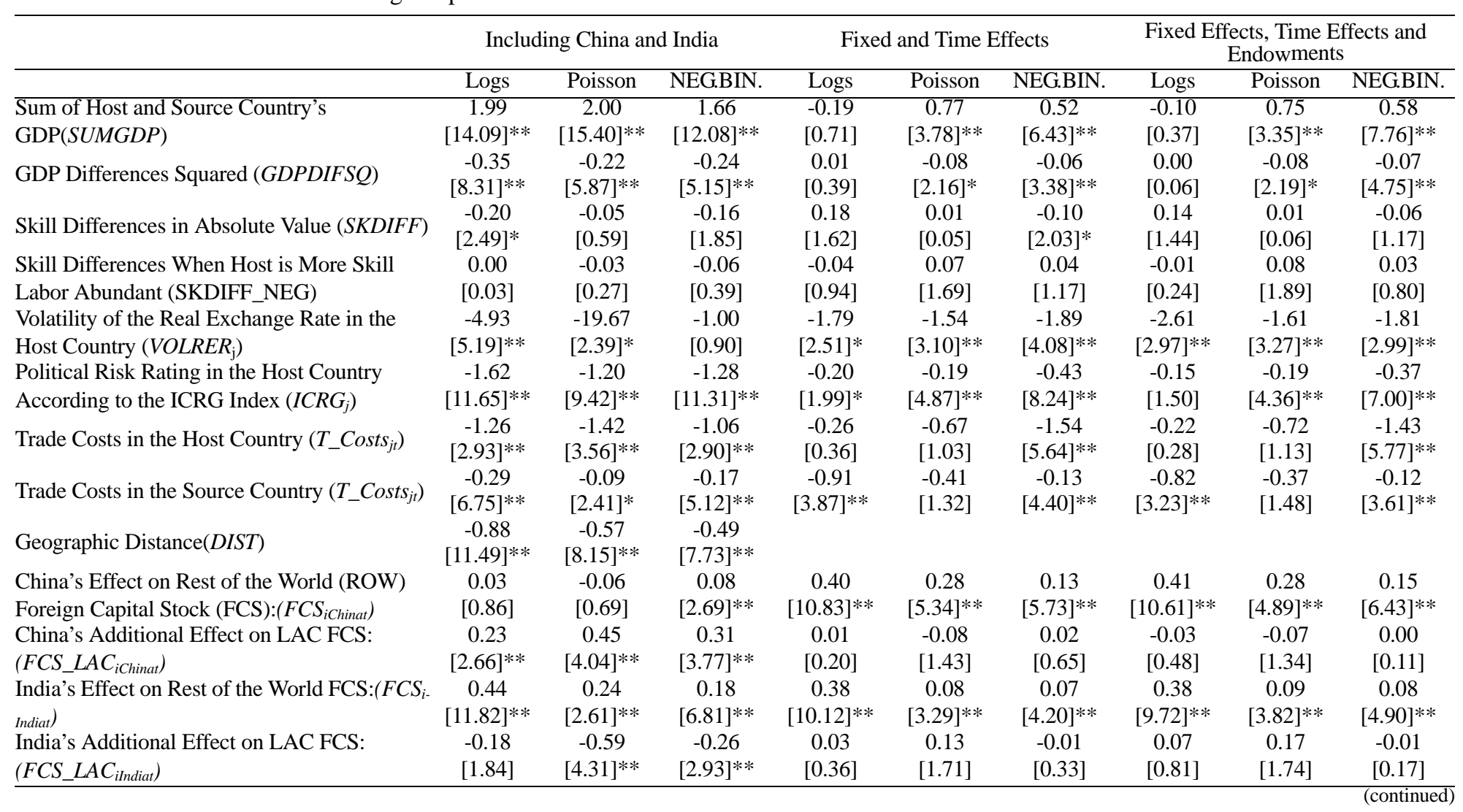


Table 2. Estimations of the Knowledge Capital Model with China and India Effects (continued)

\begin{tabular}{|c|c|c|c|c|c|c|c|c|c|}
\hline Natural Resources: Fuel & & & & & & & $\begin{array}{l}0.0000 \\
{[0.55]}\end{array}$ & $\begin{array}{l}-0.0001 \\
{[2.16]^{*}}\end{array}$ & $\begin{array}{l}0.0000 \\
{[1.33]}\end{array}$ \\
\hline Natural Resources: Mining & & & & & & & $\begin{array}{l}0.0002 \\
{[0.79]}\end{array}$ & $\begin{array}{l}0.0000 \\
{[0.10]}\end{array}$ & $\begin{array}{c}0.0000 \\
{[0.23]}\end{array}$ \\
\hline Observations & 11363 & 11363 & 11363 & 11363 & 10651 & 10651 & 9782 & 9295 & 9295 \\
\hline $\begin{array}{l}\text { Number of Group(country pairs) } \\
\text { p-value Likelihood Ratio Test Alpha }=0\end{array}$ & 1486 & $\begin{array}{c}1486 \\
0.000\end{array}$ & 1486 & 1486 & 1128 & 1128 & 1311 & 1055 & 1055 \\
\hline \multicolumn{10}{|c|}{$\begin{array}{l}\text { Robust t statistics in brackets (clusters pairid), bootstrap t-statistics in Poisson and Negative Binomial with fixed effects. Time and country-pair fixed effects are } \\
\text { included, but not reported. The panel below reports the corresponding point estimates of theffect of foreign capital stocks in China and India on LAC economies' } \\
\text { FCS. }\end{array}$} \\
\hline China's Effect on LAC & & 0.26 & 0.39 & 0.40 & 0.42 & 0.21 & 0.15 & 0.38 & 0.20 \\
\hline India's Effect on LAC & & 0.25 & -0.35 & -0.08 & 0.40 & 0.21 & 0.06 & 0.45 & 0.26 \\
\hline $\mathrm{p}$-value test: China's Effect on $\mathrm{LAC}=0$ & & 0 & 0 & 0 & 0 & 0 & 0 & 0 & 0 \\
\hline p-value test: India's Effect on LAC $=0$ & & 0.01 & 0 & 0.36 & 0 & 0 & 0.07 & 0 & 0 \\
\hline
\end{tabular}

LAC=Latin American and the Caribbean 
with the OECD/UNCTAD data, the correlation between Chinese and LAC FCS is positive and statistically significant. In contrast, we cannot reject the hypothesis that the effect of India in LAC is zero. These results are robust across the alternative estimators. The effect of China in the manufacturing sector is either positive or not significant. Indian FCS in the manufacturing sector has a negative and significant coefficient in the Poisson estimation. However, this finding is not robust across estimators. We find no effect of this variable using the OLS and a positive effect using the Negative Binomial estimator.

Table 2 reports the results from the fully specified KCM, based on the OECD and UNCTAD data. Again, the bottom panel contains the point estimates of the China and India effects on LAC's FCS. The first column shows the OLS results for our benchmark model. The results for most of the control variables are similar to those in the KCM literature and consistent with the theory. The sum of host and source country's GDP ( $S U M G D P$ ) and the square of the difference in GDP between host and source countries (GDPDIFFSQ) have the expected signs and are statistically significant. The coefficient in the skill difference is negative, which is contrary to the theory but consistent with other empirical findings (e.g., Blonigen et al 2003). We do not find a different effect for the negative skill difference. Both measures of investment cost are negative and statistically significant. The distance and the trade costs variables also have a negative coefficient and are statistically different from zero.

The estimates of the impact of Chinese and Indian FCS on other countries FCS do not show evidence of FCS substitution. The coefficient on China's FCS is not different from zero, and the interaction with the Latin American dummy is positive, suggesting that FCS in China and LAC are complements. As shown in the bottom of the table, the overall effect of China on LAC is 0.26 and statistically different from zero. Indian FCS has a positive effect on FCS for the world average, and that effect is not different for LAC. Again, the overall effect in LAC is positive and significant.

Columns 2 and 3 in Table 2 present results from Poisson and Negative Binomial estimators. The estimates of the control variables are consistent with the OLS coefficients. The coefficients on Chinese FCS, although a bit bigger, are also similar to those in the OLS regressions. Differences appear in the estimates for India. The Poisson estimator produced a significantly negative coefficient on the Indian FCS multiplied with the LAC dummy, thus making the overall effect of Indian on LAC FCS negative. The Negative Binomial estimator also shows that 
the effect of Indian FCS is different in LAC than in the rest of the world, although here we cannot reject the hypothesis that the overall effect on LAC is zero.

One potential weakness of the aforementioned specifications reported in Table 2 is that they do not control for global trends affecting FDI in China and India as well as in other developing countries. Also, estimates on the variables may be biased due to unobserved time-invariant country-pair characteristics.

The second panel in Table 2 reports the specification that controls for time and country-pair fixed effects. The KCM performs well, especially with the count data estimators. The coefficients on the sum of host and source countries' GDP and the difference in GDP squared became smaller after controlling for country-pair fixed effects in the OLS estimation. ${ }^{12}$ The first column in the second panel shows that even after controlling for time effects, the average impact of FCS in China and India are positive in the OLS estimation. The effect on LAC is not statistically different, and remains positive and significant.

Columns 6 and 7 show the Poisson and Negative Binomial results, using the conditional mean estimators. The estimates on the effects of China and India are consistent with those in the OLS. The impact of China and India on the rest of the world's FCS is positive and significant, and it is not different for LAC.

The last panel of Table 2 presents the fixed-effects results that also control for natural resource abundance in the host countries. The coefficients on these latter variables are not different from zero. Only in the Poisson model the fuel abundance variable appears significant and has a negative sign, indicating that abundance of fuel resources is negatively correlated with FCS. The estimates of the Chinese and Indian variables remain unchanged, however.

One concern about these results is related to the data, which might underestimate China's FCS. Hong Kong has been a part of China since 1997 and therefore should be considered part of the Chinese economy. Moreover, some observers have argued that China's and Hong Kong's trade data should be combined to approximate the trade flows coming from mainland China due to transshipments of merchandise through Hong Kong (Fernald et al. 1998). Hong Kong has a significant contribution in the marketing and distribution of Chinese exports, thus making it difficult to differentiate the value added in each country. Similarly, multinational enterprises may be moving to Hong Kong to conduct activities in mainland China.

\footnotetext{
${ }^{12} \mathrm{We}$ include the time effects and the fixed effects one at a time. The comparison of these results indicates the fixed effects are driving these results.
} 
Table 3. Evidence within Sectors Using the US as the Only Source Country

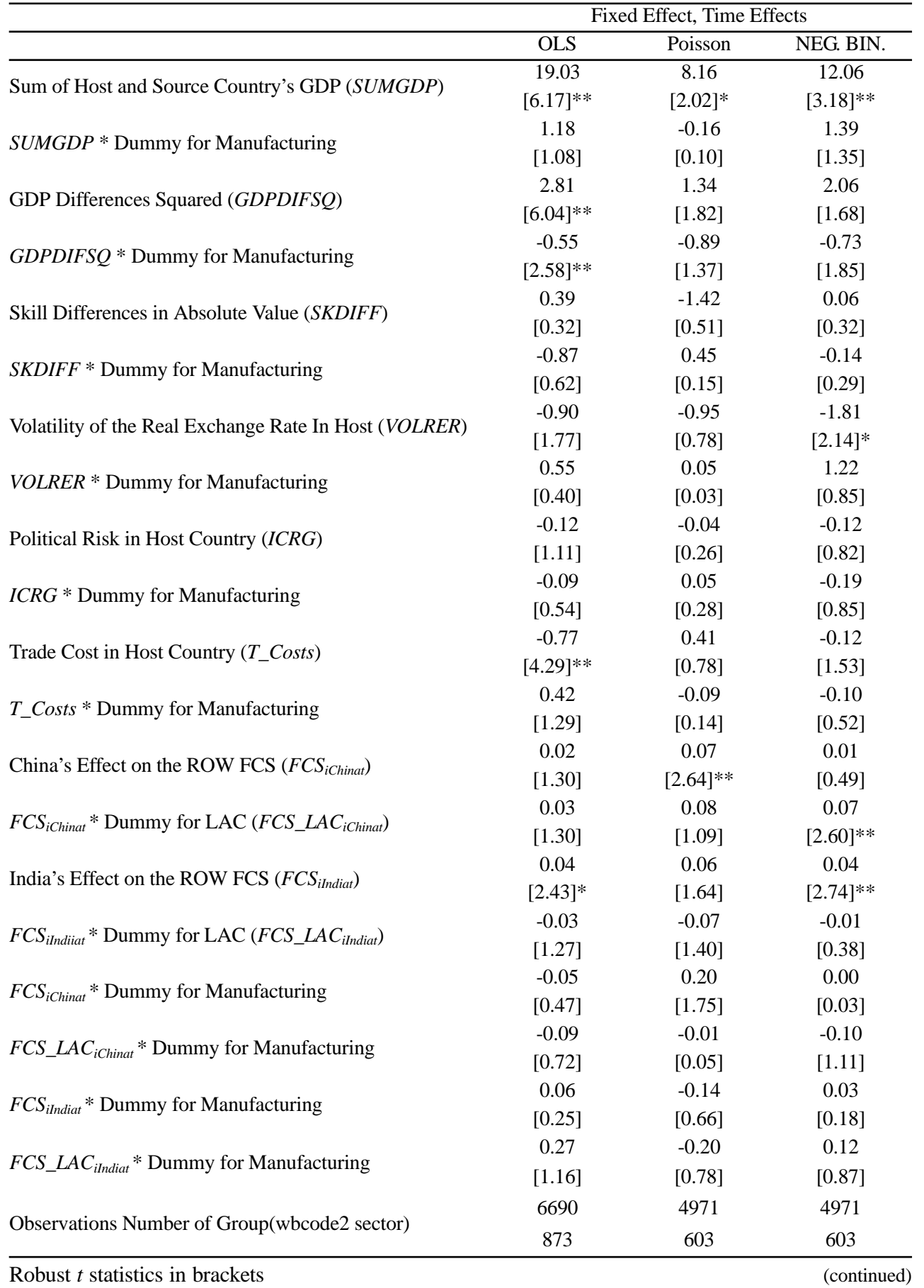

* significant at 5\%; ** significant at $1 \%$ 
Table 3. Evidence within Sectors Using the US as the Only Source Country (continued)

\begin{tabular}{lccc}
\hline China's Effect on LAC & 0.04 & 0.15 & 0.08 \\
India's Effect on LAC & 0.01 & -0.01 & 0.03 \\
China's Effect on LAC Manufacturing & -0.10 & 0.34 & -0.02 \\
India's Effect on LAC Manufacturing & 0.33 & -0.35 & 0.18 \\
p-value test: China Effect on LAC=0 & 0.02 & 0.03 & 0.00 \\
p-value test: India Effect on LAC=0 & 0.74 & 0.76 & 0.26 \\
p-value test: China Effect on LAC Manufacturing=0 & 0.43 & 0.01 & 0.81 \\
p-value test: India Effect on LAC Manufacturing=0 & 0.16 & 0.26 & 0.35 \\
\hline
\end{tabular}

LAC $=$ Latin American and the Caribbean

Also, FDI from third countries may be channeled through Hong Kong even prior to 1997 (Fung 1997).

To deal with these potential issues, we summed China and Hong Kong FCS and repeated the econometric analyses. The results remain unchanged and for the sake of brevity are not reported here. ${ }^{13}$ There is still no evidence of a substitution effect between China-Hong Kong and other countries, including LAC, and there is some evidence of complementarities.

In spite of this evidence, there is still the possibility that the emergence of China and India may have taken foreign investment in some sectors from other developing economies. Cravino, Lederman, and Olarreaga (2006) highlighted trends in FCS in the manufacturing sector in China, India, and Latin America that may differ from trends in aggregate FCS. As a robustness check, the following section thus discusses results based on U.S. foreign investment data across industries.

\section{A. U.S. Foreign Investment across Sectors}

To deal with the potential heterogeneity across sectors, with an emphasis on manufacturing industries, here we repeat the analysis using U.S. sector FCS data. Our benchmark specification is again the KCM in logs. We include all the previously discussed explanatory variables, and also an interaction of all these variables with a dummy for the manufacturing sector. Again, we include time dummies and fixed effects in the estimations. ${ }^{14}$

\footnotetext{
${ }^{13}$ These results are available from the authors upon request.

${ }^{14}$ In the conditional-mean Negative Binomial specification we also include a dummy for the manufacturing sector. This is possible because the Conditional Mean estimator proposed by Hausman, Hall, and Griliches (1984) does not control for all stable covariates -- see Alison and Waterman (2002).
} 
The use of the U.S. data makes it impossible to estimate the effect of distance and source country trade costs together with time and host country effects, since the U.S. appears as the only source country in this sample. Also, since the U.S. is more skilled labor abundant than any other country in the dataset, there is no need to take the absolute value of the skill difference between the source and host countries. The results for these estimates are reported in Table 3, where the bottom panel of the tables shows the point estimates of the effects of Chinese and Indian FCS on LAC FCS.

The first column of the table shows the OLS estimation. Again, we do not find any evidence of substitution in these estimations. Although none of the variables of interest are statistically different from zero, the overall coefficient of the effect of China on LAC is positive and significant, which is consistent with our previous estimates. The overall coefficient for India is also positive, but not statistically different from zero. There is no evidence of an impact of China on U.S. FCS in other countries' manufacturing industries. The overall coefficient for India on the other hand is 0.33 and significant at the 10 percent level.

The second column of Table 3 shows the Poisson estimates. As in the OLS estimation, the overall impact of China on LAC continues to be positive and significant and the overall impact of India on LAC is not different from zero. The impact of China in the manufacturing sector continues to be positive. Finally, the negative coefficient of the impact of China in LAC manufacturing is no longer significant once we control for the KCM variables, thus shedding more doubts on the substitution hypothesis.

The last column shows the results of the Negative Binomial estimator. The signs of the coefficients for the aggregate effect of China and India are consistent with the other estimators. However, as in the OLS estimation, we cannot reject the hypothesis that the impact of China in LAC manufacturing FCS is zero. The effect of India continues to be statistically insignificant.

As a robustness check, we repeated the sector analysis by using the sum of China's (mainland) and Hong Kong's FCS instead of China alone as the proxy for the effects from China. The results remain virtually unchanged. We continue to find that there is no substitution effect between FCS in China and India and those in LAC in the manufacturing sector. ${ }^{15}$

In sum, using U.S. data we continue to find that the impact of China has been

${ }^{15}$ These results are available from the authors upon request. 
positive for LAC FCS but not necessarily for other economies. This was not the case in the manufacturing sector, where we found that China had no impact at all. In contrast, we do not find an overall impact from India with these data. The evidence in the manufacturing sector is less clear, although our preferred Negative Binomial estimator yielded a positive effect of India on LAC FCS in manufacturing activities.

\section{B. Heterogeneity within Latin America}

It is possible that China and India have had different effects across LAC countries. For example, China may be having a negative impact in those countries where assembly operations (the so-called maquilas) are important, but not in other countries. We therefore divide LAC countries into three sub regions, roughly according to their production structure. These sub regions are Central America, the Caribbean, and Mexico where maquilas are commonplace, Andean countries that tend to export a combination of agricultural and labor-intensive products as well as petroleum, and the Southern Cone countries that have vast natural resources, especially arable land. ${ }^{16}$

The results are reported in Table 4. For the sake of brevity, we only report estimates of the effect of Chinese and Indian FCS on the Latin American country groups. The first panel of the table shows the estimates using the bilateral data from OECD and UNCTAD. We find that the results for the three sub regions are similar to those of LAC as a whole. That is, we do not find a negative effect of either China or India on any of the sub regions, and there is still evidence of complementarities.

The second panel of Table 4 reports estimates of the effects of China and India on total U.S. stocks in the three sub regions. We continue to find no evidence of substitution effects. The positive effect for LAC as a whole, however, is only significant for the Southern Cone. The overall effect of India on U.S. stocks continues to be zero for all sub regions.

The last panel of Table 4 reports the effects of China and India on FCS in the manufacturing sectors of Latin America. We find heterogeneity across sub regions. The coefficient of China is negative for Central America in the OLS specification,

\footnotetext{
${ }^{16}$ Central America: Costa Rica, Dominican Republic, El Salvador, Guatemala, Haiti, Honduras, Jamaica, Mexico, Nicaragua, Panama, and Trinidad and Tobago. Andean: Bolivia, Colombia, Ecuador, Peru and Venezuela. Southern Cone: Argentina, Brazil, Chile, Paraguay, and Uruguay.
} 
Table 4. China and India Effects across LAC Sub Regions

\begin{tabular}{|c|c|c|c|c|c|c|c|c|c|}
\hline & \multicolumn{3}{|c|}{ Aggregate Data } & \multicolumn{3}{|c|}{ U.S. Data } & \multicolumn{3}{|c|}{ U.S. Data: Manufacturing } \\
\hline & OLS & Poisson & Neg. Bin. & OLS & Poisson & Neg. Bin. & OLS & Poisson & Neg. Bin. \\
\hline \multirow{2}{*}{ China's Effect on Central American Countries } & 0.45 & 0.22 & 0.13 & 0.02 & 0.20 & 0.05 & -0.33 & 0.27 & -0.06 \\
\hline & {$[0.00]^{* *}$} & {$[0.06]^{*}$} & {$[0.02]^{* *}$} & {$[0.47]$} & {$[0.31]$} & {$[0.14]$} & {$[0.03]^{* *}$} & [0.29] & {$[0.56]$} \\
\hline \multirow{2}{*}{ India's Effect on Central American Countries } & 0.34 & 0.18 & 0.02 & 0.01 & -0.01 & 0.01 & 0.86 & -0.10 & 0.16 \\
\hline & {$[0.01]^{* *}$} & [0.45] & {$[0.70]$} & {$[0.64]$} & {$[0.83]$} & {$[0.83]$} & {$[0.00]^{* *}$} & [0.89] & {$[0.46]$} \\
\hline China's Effect on Andean Countries & 0.48 & 0.29 & 0.18 & 0.03 & 0.11 & 0.13 & 0.07 & 0.37 & -0.01 \\
\hline India's Effect on Andean Countries & {$[0.00]^{* *}$} & {$[0.06]^{*}$} & {$[0.58]$} & {$[0.77]$} & {$[0.78]$} & [0.97] & [0.94] & {$[0.26]$} & {$[0.60]$} \\
\hline \multirow{2}{*}{ China's Effect on Southern Cone's Countries } & 0.24 & 0.20 & 0.15 & 0.08 & 0.09 & 0.09 & 0.24 & 0.43 & 0.09 \\
\hline & {$[0.02]^{* *}$} & {$[0.01]^{* *}$} & {$[0.00]^{* *}$} & {$[0.00]^{* *}$} & {$[0.02]^{* *}$} & {$[0.03]^{* *}$} & {$[0.12]$} & {$[0.01]^{* *}$} & {$[0.63]$} \\
\hline \multirow{2}{*}{ India's Effect on Southern Cone's Countries } & 0.59 & 0.28 & 0.15 & -0.02 & 0.01 & 0.07 & -0.37 & -0.58 & 0.07 \\
\hline & {$[0.00]^{* *}$} & {$[0.02]^{* *}$} & {$[0.00]^{* *}$} & {$[0.60]$} & {$[0.90]$} & [0.17] & {$[0.13]$} & {$[0.05]^{*}$} & {$[0.78]$} \\
\hline
\end{tabular}

p-values in brackets correspond to the F-test of the null hypothesis that the effect $=0$. All estimates come from estimations of the fully specified KCM, but other parameter estimates are not reported.

$*$ significant at $5 \%$;** significant at $1 \%$. 
Negative Binomial estimators. There is no evidence that growing FCS in China have had a negative impact on the FCS of the other two regions. The OLS results for India are in general not significant and do not differ much across sub regions. In contrast, the Poisson estimator has a negative coefficient, but this result is not robust as it is not obtained with the alternative estimators.

In brief, the conclusions drawn from previous sections apply across LAC sub regions. The results for the aggregate bilateral stocks from the OECD do not show much variation across regions within LAC, and strongly support the complementarity hypothesis. The overall effects of China and India are less important in the U.S. data, and the positive effect of China found for LAC in section IV.A is mainly due to its positive effect in the Southern Cone countries' FCS.

Differences across sub regions come out in the manufacturing sector data, where there is surprisingly weak evidence that China and India might have had negative effects on Central America and the Southern Cone respectively, as these results are not robust across estimators.

\section{Conclusions}

In this paper, we empirically estimate the effects of China and India on foreign investment in other economies, with special emphasis on Latin America. Using bilateral outward stocks data from UNCTAD and OECD, we find that China and India had a positive average effect on the FCS in Latin America and the rest of the world. This result is robust to the use of Poisson and Negative Binomial estimators and to the inclusion of time dummies and country-pair fixed effects. The evidence based on U.S. foreign investment data across industries also suggests that the effect of China has been positive on aggregate for all sectors, but there is little evidence that this is the case in the manufacturing sector. It is worth mentioning that there is some evidence of a negative average effect on Central American economies (which includes Mexico and Caribbean countries), although this evidence is not robust across estimators. In contrast, India appears to have had no impact on the U.S. stock of foreign capital in LAC. We do find some evidence of Indian substitution effects in the manufacturing sector when we concentrate on the Southern Cone countries, but this finding is not robust to the use of the Negative Binomial estimator.

The preponderance of the evidence thus suggests that the emergence of China 
and India in the global economy has had positive effects on global FDI flows. Fears of a global competition for FDI consequently seem misplaced in light of the data. Policymakers concerned about attracting foreign investors into their economies should focus their efforts on the fundamental determinants of FDI. The KCM model seems to be broadly supported by the global data, and is thus useful for thinking about policies that will attract FDI, including trade reforms, dealing with macroeconomic volatility, and other pro growth-reforms.

\section{Acknowledgements}

We are grateful to Pravin Krishna, Gordon Hanson, Guillermo Perry, Luis Servén, Beata Javorcik, the Editor, and an anonymous referee for insightful comments. Financial support from the World Bank's Latin American and Caribbean Regional Studies Program is gratefully acknowledged. The findings, interpretations and conclusions expressed in this paper are entirely those of the authors. They do not necessarily represent the view of the World Bank, its Executive Directors, or the countries they represent.

Received 18 September 2007, Revised 22 January 2008, Accepted 01 February 2008 


\section{Appendix}

Table A1. Summary Statistics

\begin{tabular}{|c|c|c|c|c|c|}
\hline Variable & Observations & Mean & Std. Dev. & Min & Max \\
\hline Foreign Capital Stock $\left(F C S_{i j t}\right)$ & 13765 & 3379.089 & 15004.25 & 0 & 322733.4 \\
\hline $\begin{array}{l}\text { Sum of Host and Source GDP } \\
\left(S U M G D P_{i j t}\right)\end{array}$ & 13765 & 2090.304 & 2772.533 & 12.61177 & 14743.19 \\
\hline $\begin{array}{l}\text { Difference in Host and Source GDP } \\
\text { Squared }\left(G D P D I F F S Q_{i j t}\right)\end{array}$ & 13765 & 9708931 & $2.45 \mathrm{E}+07$ & 0.0114306 & $1.11 \mathrm{E}+08$ \\
\hline $\begin{array}{l}\text { Absolute Value of Skill Differences } \\
\left(S K I D I F F i_{j t}\right)\end{array}$ & 13765 & 1.000673 & 0.65493 & 0.0000104 & 2.702084 \\
\hline $\begin{array}{l}\text { Volatility of the Real Exchange rate in } \\
\text { Host }\left(V_{\left.O L L E R_{j t}\right)}\right.\end{array}$ & 13765 & 0.025836 & 0.034664 & 0.0022654 & 0.621135 \\
\hline Political Risk Index in Host $\left(I C R G_{j t}\right)$ & 13765 & 28.71217 & 13.18151 & 3 & 87 \\
\hline Trade Cost in Host $\left(T_{-} C O S T_{j t}\right)$ & 13765 & 74.8935 & 10.90686 & 7.473358 & 95.12417 \\
\hline Trade Cost in Source $\left(T_{-} C O S T_{i t}\right)$ & 13765 & 68.83891 & 20.26945 & 0.1 & 97.11642 \\
\hline $\begin{array}{l}\text { Geographic Distance between Host and } \\
\text { Source }\left(D I S T_{i j t}\right)\end{array}$ & 13765 & 3935.745 & 2576.506 & 137.2279 & 12272.34 \\
\hline $\begin{array}{l}\text { Foreign Capital Stock of Source in } \\
\text { China }\left(F C S_{\text {iChinat }}\right)\end{array}$ & 12666 & 1764.356 & 3186.026 & 0.098907 & 22096.84 \\
\hline $\begin{array}{l}\text { Foreign Capital Stock of Source in } \\
\text { India }\left(F C S_{\text {iIndiat }}\right)\end{array}$ & 12173 & 514.8716 & 866.7437 & 0.0960905 & 5613.682 \\
\hline
\end{tabular}

Table A2. Countries Included in the Aggregate-Data Regressions

\begin{tabular}{cccc}
\hline Source countries & LAC host countries & \multicolumn{2}{c}{ Other host countries } \\
\hline Australia & Argentina & Algeria & Malawi \\
Austria & Bolivia & Austria & Malaysia \\
Belgium & Brazil & Bahrain & Mali \\
Brazil & Chile & Bangladesh & Moldova \\
Bulgaria & Colombia & Belgium & Mozambique \\
Canada & Costa Rica & Botswana & Netherlands \\
Colombia & Dominican Republic & Bulgaria & Niger \\
Denmark & Ecuador & Cameroon & Norway \\
Estonia & El Salvador & Canada & Pakistan \\
Finland & Guatemala & Congo, Dem. Rep. & Philippines \\
France & Guyana & Congo, Rep. & Poland \\
Germany & Haiti & Denmark & Portugal \\
Greece & Honduras & Egypt, Arab Rep. & Romania \\
Hungary & Jamaica & Estonia & Russian Federation \\
Iceland & Mexico & Finland & Senegal \\
Ireland & Nicaragua & France & Sierra Leone \\
\hline
\end{tabular}


Table A2. Countries Included in the Aggregate-Data Regressions (continued)

\begin{tabular}{cccc}
\hline Italy & Panama & Gambia, The & Singapore \\
\hline Japan & Paraguay & Germany & South Africa \\
Kazakhstan & Trinidad and Tobago & Ghana & Spain \\
Korea, Rep. & Uruguay & Greece & Sri Lanka \\
Mexico & Venezuela, RB & Guinea-Bissau & Sudan \\
Netherlands & & Hong Kong, China & Sweden \\
New Zealand & Hungary & Switzerland \\
Norway & Indonesia & Syrian Arab Republic \\
Poland & Iran, Islamic Rep. & Taiwan, China \\
Portugal & Ireland & Tanzania \\
Spain & Israel & Thailand \\
Sweden & Italy & Togo \\
Switzerland & Japan & Tunisia \\
Turkey & Jordan & Turkey \\
United Kingdom & Kazakhstan & Uganda \\
United States & Kenya & United Kingdom \\
& & Korea, Rep. & United States \\
& Kuwait & Vietnam \\
& Latvia & Yemen, Rep. \\
& Liberia & Zambia \\
& & Zimbabwe
\end{tabular}

\section{References}

Allison, Paul D., and Richard P. Waterman (2002), "Fixed Effects Negative Binomial Regression Models", Sociological Methodology 32: 247-65.

Barro, Robert J. and Jong-Wha Lee (2000), "International Data on Educational Attainment: Updates and Implications", Harvard University, February.

Blonigen, Bruce, Ronald B. Davies and Keith Head (2003), "Estimating the KnowledgeCapital Model of the Multinational Enterprise: Comment", American Economic Review 93: 980-994.

Blonigen, Bruce, and Ronald B. Davies (2004), "The Effects of Bilateral Tax Treaties on U.S. FDI Activity", International Tax and Public Finance 11: 601-622.

Carr, David L., James R. Markusen, and Keith E. Maskus (2001), "Estimating the Knowledge-Capital Model of the Multinational Enterprise", American Economic Review 91: 693-708.

Carr, David L., James R. Markusen, and Keith E. Maskus (2003), "Estimating the Knowledge-Capital Model of the Multinational Enterprise: Reply", American Economic Review 93: 995-1001. 
Chantasasawat, Busakorn, K.C. Fung, Hitomi Lizaka, and Alan Siu (2004), "FDI Flows to Latin America, East and Southeast Asia and China: Substitutes or Complements?" Department of Economics, University of California, Santa Cruz, Working Paper 595.

Cravino, Javier, Daniel Lederman, and Marcelo Olarreaga (2006), "Foreign Direct Investment in Latin America during the Emergence of China and India: Stylized Facts", www.worldbank.org/laceconomist.

García-Herrero, Alicia, and Daniel Santabárbara (2005), "Does China Have an Impact on Foreign Direct Investment to Latin America?", Banco de España, Madrid, Documento de Trabajo N 0517.

Eichengreen, Barry, and Hui Tong (2005), "Is China FDI Coming at the Expense of Other Countries?", NBER Working Paper 11335, Cambridge, MA.

Fernald, John, Hali Edison, and Prakash Loungani (2004), "Was China the First Domino? Assessing Links between China and the Rest of Emerging Asia," Board of Governors of the Federal Reserve System, International Finance Discussion Paper 604, Washington, DC.

Fung, K.C (1997), "Trade and Investment Flows: Mainland China, Hong Kong, and Taiwan", Hong Kong, China: City University of Hong Kong Press.

Hausman, Jerry, Bronwyn Hall, and Zvi Griliches (1984), "Econometric Models for Count Data with an Application to the Patents-R\&D Relationship", Econometrica 52: 909-38.

Markusen, James R., and Keith E. Maskus (2002), "Discriminating among Alternative Theories of the Multinational Enterprise", Review of International Economics 10: 694-707.

Markusen, James R., and Keith E. Maskus (1999), "Multinational Firms: Reconciling Theory and Evidence", NBER Working Paper 7163, Cambridge, MA.

Mercereau, Benoît (2005), "FDI Flows to Asia: Did the Dragon Crowd Out the Tigers?", IMF Working Paper, www.imf.org.

Santos Silva, J.M.C. and Silvana Tenreyro (2006), "The Log of Gravity”, The Review of Economics and Statistics 88: 641-658.

UNCTAD [United Nations Conference on Trade and Development] (2004), World Investment Directory, Geneva and New York: United Nations.

UNCTAD. 2005. World Investment Report, Geneva and New York: United Nations. 